\title{
Epizootiology of Perkinsus sp. in Crassostrea gasar oysters in polyculture with shrimps in northeastern Brazil
}

\author{
Epizootiologia de Perkinsus sp. em ostras Crassostrea gasar em policultivo com \\ camarôes no Nordeste do Brasil \\ Patricia Mirella da Silva ${ }^{1 *}$; Carolina Pereira $\operatorname{Costa}^{1}$; Jaíse Paiva Bragante de Araújo후 \\ Fernando Ramos Queiroga ${ }^{1}$; Alexandre Alter Wainberg ${ }^{2 \dagger}$ \\ ${ }^{1}$ Laboratório de Imunologia e Patologia de Invertebrados, Departamento de Biologia Molecular, Centro de Ciências Exatas e da \\ Natureza, Universidade Federal da Paraíba - UFPB, João Pessoa, PB, Brasil \\ ${ }^{2}$ Fazenda PRIMAR, Tibau do Sul, RN, Brasil \\ $\dagger$ In memoriam
}

Received August 21, 2015

Accepted January 13, 2016

\begin{abstract}
Bivalve culture is of considerable economic and social interest in northeastern (NE) Brazil. The polyculture is an alternative approach to traditional monoculture for reducing the environmental impact of shrimp farming and improving oyster culture. Perkinsus marinus and Perkinsus olseni were found infecting oysters in NE Brazil and can threaten oyster production. This study evaluated Perkinsus spp. occurrence in Crassostrea gasar during all production stages. Oyster spats were produced in a hatchery and grown in shrimp ponds in Rio Grande do Norte state. Perkinsus spp. were surveyed by Ray's fluid thioglycollate medium and confirmed by polymerase chain reaction. Prevalence and intensity of infection were determined in oysters until they reached $7 \mathrm{~cm}$. Results showed that the broodstock was already infected by Perkinsus (60\%), but the derived spats were Perkinsus-free. Oyster spats acquired Perkinsus infection when transferred to ponds. The prevalence gradually increased in the seven months following placement in ponds (73\%), and then decreased to $17 \%$ by the tenth month. The infections were initially mild, but intensity increased at the final growth stage. In conclusion, it is possible to produce Perkinsus-free C. gasar oyster spats from infected broodstock, and their culture in shrimp ponds is feasible.
\end{abstract}

Keywords: Crassostrea gasar, hatchery, oyster, polyculture, Perkinsus sp., sanitary control.

\section{Resumo}

O cultivo de bivalves é de grande interesse econômico e social no Nordeste (NE) do Brasil. O policultivo é uma alternativa ao monocultivo tradicional de camaróes para reduzir o impacto ambiental e melhorar a produção de ostras. Perkinsus marinus e Perkinsus olseni foram identificados infectando ostras no Nordeste do Brasil e representam uma ameaça a produção de ostras. Este estudo avaliou a ocorrência de Perkinsus spp. em Crassostrea gasar durante todas as fases de produção. Sementes de ostras foram produzidas em laboratório e cultivadas em viveiros de camarão no Rio Grande do Norte. Perkinsus spp. foram diagnosticados com o uso do meio de tioglicolato fluido de Ray e confirmado por reação em cadeia da polimerase. A prevalência e intensidade de infecção foram determinadas em ostras até atingirem $7 \mathrm{~cm}$. Os resultados mostraram que os reprodutores encontravam-se infectados por Perkinsus (60\%), mas as sementes produzidas estavam livres de Perkinsus. As sementes adquiriram a infecção por Perkinsus quando transferidas para os viveiros. A prevalência aumentou gradualmente nos sete meses após a colocação nos viveiros (73\%) e, em seguida, diminuiu para $17 \%$ até o décimo mês. As infecçôes foram inicialmente leves, mas aumentaram até a fase final do crescimento. Em conclusão, é possível produzir sementes de ostras C. gasar livres de Perkinsus a partir de reprodutores infectados e seu cultivo em viveiros de camarão é viável.

Palavras-chave: Crassostrea gasar, unidade de reprodução, ostras, policultivo, Perkinsus sp., controle sanitário.

\footnotetext{
*Corresponding author: Patricia Mirella da Silva. Laboratório de Imunologia

e Patologia de Invertebrados, Departamento de Biologia Molecular, Centro de Ciências Exatas e da Natureza, Universidade Federal da Paraíba - UFPB,

Campus I, CEP 58051-900, João Pessoa, PB, Brasil.

e-mail: mirella_dasilva@hotmail.com
} 


\section{Introduction}

The culture of mollusks is of considerable economic and social interest in a number of countries worldwide, including Brazil. The state of Santa Catarina is the largest national producer of mollusks and the second largest in Latin America, with an annual production of 21,553 tons in 2014. Nevertheless, just 3,600 tons correspond to the Japanese oyster Crassostrea gigas (EPAGRI, 2014), highlighting the potential for increasing the national production of oysters. Crassostrea gigas was introduced into Brazil in the 1970s and quickly adapted to the climate conditions of the Santa Catarina state (south Brazil). The Laboratory of Marine Mollusks (LMM) of the Federal University of Santa Catarina (UFSC) has been a pioneer in improving the technical procedures for production of $C$. gigas spat in Brazil and in transferring technologies for its growth to the production sector. Currently, much of the production of $C$. gigas oysters in the state of Santa Catarina depends on the spats produced by LMM.

The northeastern (NE) coast of Brazil is known for the presence of large estuaries inhabited by numerous species of edible bivalves, including two species of oysters, Crassostrea gasar and Crassostrea rhizophorae. Due to high primary productivity in the seawater and favorable climatic and geographic conditions in these environments, the NE region shows great potential for increasing the development of oyster culture (LAVANDER et al., 2013).

Unlike Santa Catarina, oyster production in the NE region faces many obstacles, including various economic and, particularly, technical (lack of specialized technical assistance) difficulties. The production is based primarily on oyster collection from natural estuarine populations, which does not allow for oysters with assured sanitary or productivity qualities. Therefore, the inability to select oysters with a good growth rate and appearance is one of the disadvantages of the traditional culture methods that prevail in the NE region today.

In Brazil, there are currently no hatchery facilities for native oysters because production techniques have not been fully optimized for these species. However, some efforts have been made by research institutions to understand certain biological aspects of C. gasar that may be useful in the production process (LOPES et al., 2013; RAMOS et al., 2014; SILVEIRA et al., 2011; GOMES et al., 2014).

Shrimp culture is the dominant aquaculture activity in the $\mathrm{NE}$ region, however, this practice is known to negatively impact water quality of the surrounding estuaries (PÁEZ-OSUNA, 2001). Thus, in order to minimize the environmental impact of shrimp farm effluents and promote sustainable aquaculture as well as improve oyster culture in the NE region, implementation of polycultures is a good alternative (RAMOS et al., 2008; REYES, 2013; ROSA, 2014; MARTINEZ-PORCHAS et al., 2010). It is known that shrimp pond water quality can be improved by the use of filter feeding bivalves such as oysters, which can help decrease the concentration of total suspended solids, organic and inorganic matter, nitrogen, phosphorous, chlorophyll a and bacteria (JONES et al., 2001; JONES \& PRESTON, 1999; MARTINEZCORDOVA \& MARTINEZ-PORCHAS, 2006; RAMOS et al., 2008). The improvement of pond water quality contributes to improved growth performance and health of the shrimp (XIE et al., 2011; REYES, 2013). Xie et al. (2011) recorded an increase in body length and fresh and dry weight of shrimps cultured in ponds with clams. Oysters or other bivalves may benefit from the high concentration of nutrient particles available in shrimp ponds leading to improved growth (MARTINEZ-CORDOVA \& MARTINEZ-PORCHAS, 2006).

The production of oysters is also threatened by the emergence of epizootic diseases, mainly caused by bacteria and protozoa (LAUCKNER, 1983; OIE, 2006). Protozoan species of the genus Perkinsus are a well-known cause of mortality in bivalve populations and consequently have a negative impact on the economy (VILLALBA et al., 2004, 2011; CHOI \& PARK, 2010). Two species, $P$. marinus and $P$. olseni, are the most pathogenic and, thus, require mandatory notification to the World Organization for Animal Health (OIE, 2015). The disease can affect all ages of oysters, from spat to adult (PAYNTER et al., 2010).

In Brazil in 2013, one parasite from this genus (P. beihaiensis) was detected for the first time infecting the oyster $C$. rhizophorae from Ceará state, with low prevalence and intensity (SABRY et al., 2009, 2013). This species was recently identified infecting the clam Anomalocardia brasiliana, as well (FERREIRA et al., 2015). In contrast, $P$. marinus was detected in two oyster species, C. rhizophorae and C. gasar from Paraíba state with high prevalence (71\% to $100 \%)$ and moderate mean intensities (SILVA et al., 2013; QUEIROGA et al., 2015). Perkinsus marinus was also detected in C. gasar from Sergipe state, although the prevalences in oysters varied seasonally (7\% in July to $80 \%$ in December) and was higher in cultured oysters (56\%) than wild oysters (35\%) (SILVA et al., 2014). Perkinsus olseni was also identified in the oyster C. gasar from Sergipe. However, it seems that this protozoan species occurs with a very low prevalence because few nucleotide sequences are obtained from host tissues (SILVA et al., 2014). In Bahia state, an unidentified Perkinsus sp. was reported in C. rhizophorae with variable prevalence (21\% to $92 \%)$ and moderate intensity. Despite the high prevalence and intensity of Perkinsus spp. infection in Brazilian oysters, a massive mortality event has not yet been reported.

In the current study, Perkinsus sp. infection was detected for the first time in C. gasar oysters from the state of Rio Grande do Norte, and the prevalence and intensity of this protozoan was evaluated in oysters produced in the hatchery and cultured in shrimp ponds.

\section{Materials and Methods}

\section{Collection of oysters}

The PRIMAR farm located in Tibau do Sul, state of Rio Grande do Norte, RN (6 13'31.06” S; 35 8' 19.92” W) produces organic shrimps (3-4 animals per $\mathrm{m}^{2}$, without supplementary feeding) and oysters in shrimp ponds. The farm has recently implemented (2014) a hatchery facility for oyster spats production. Crassostrea gasar oyster spats were produced in a hatchery and grown in shrimp ponds at the PRIMAR farm. The water temperature and 
salinity of the ponds were monitored daily throughout the oyster growth period (July 2014 to May 2015).

Table 1 lists the dates, number of oysters sampled at each production stage and type of analysis performed.

The first sampling of oysters $(n=10)$ was conducted in February 2013 for a preliminary evaluation of the presence of Perkinsus spp. in adult oysters cultured for more than three years at the PRIMAR farm to use as breeders.

On April 12, 2014, 160 adult oysters (breeders from PRIMAR) were divided into two polyethylene tanks (1000 L; 80 individuals/tank) to undergo mass spawning. Spawning occurred on April 13 and resulted in 180 million D larvae. At this time, 12 breeder oysters were sampled to detect Perkinsus spp.

The D larvae were placed in $150 \mathrm{~L}$ cylindrical-conical tanks with a continuous flow-through system with treated seawater $(25 \mathrm{psu})$, i.e. chlorinated with sodium hypochlorite solution at $20 \mathrm{mg}$ per $\mathrm{L}$ of free-chlorine, filtrated up to $1 \mu \mathrm{m}$, and sterilized by ultraviolet (UV)-C lamps (95W. 50/60 Hz, wavelength of $254 \mathrm{~nm}$ ) arranged in series, resulting in a dose around $30,000 \mu \mathrm{W} / \mathrm{cm}^{2}$. Settlement occurred in shell powder on April 27. The spats were subsequently transferred to tanks in a down-welling system, inside the hatchery. On May 2014, after 45 days of spawning, spats were sampled before being introduced into the shrimp culture ponds. Nine pools of spats were prepared, each weighing $400 \mathrm{mg}$.

In May 2014, spats were transferred to box-type tanks of 1-mm-mesh, hanging from cords supported by stakes stuck into the bottom of the pond. In July 2014, spats were sampled ( $n=50)$. After the July sampling, oysters were separated by size. This is a common practice among oyster farmers, in order to separate oysters with different growth rates. The larger oysters were placed in plastic bags with a 9-mm mesh, and the smaller oysters were placed in plastic bags with a 4-mm mesh. Because of their rapid growth, the larger oysters were separated by the producer for use as breeders in the future.

In October $2014(\mathrm{n}=50)$ and February $2015(\mathrm{n}=30)$ juvenile oysters were sampled. In March $(n=10)$ and May 2015 $(\mathrm{n}=100)$ adult oysters were sampled. Sampling performed in March corresponded to the larger oysters separated in July 2014.

\section{Diagnosis of Perkinsus spp. by Ray's fuid thioglycollate medium}

Oysters ( $n=262$; Table 1 ) were opened by cutting the adductor muscle to remove the demibranches, which were placed in tubes containing Ray's fluid thioglycollate medium (RFTM) supplemented with antibiotics, penicillin/streptomycin (final concentration $100 \mathrm{U} / \mathrm{mL}$ and $0.1 \mathrm{mg} / \mathrm{mL}$, respectively), and nystatin $(100 \mathrm{U} / \mathrm{mL})$. The tubes were placed in the dark at room temperature $\left(25^{\circ} \mathrm{C}\right)$ for seven days. After this period, demibranches were chopped into small pieces, stained with Lugol's solution (4\%) and examined by light microscopy. The samples were analyzed to determine the presence and the number of Perkinsus spp. hypnospores. The animals were classified according to Ray's scale (1954) adapted by Silva et al. (2013) as described below: Null infection (0): No hypnospores observed on the whole slide (100x);

Very light infection (1): Up to 10 hypnospores observed in the whole slide $(100 x)$;

Light infection (2): 11-100 hypnospores observed in the whole slide (100x);

Moderate infection (3): Up to 40 hypnospores observed in a total of 10 random fields $(400 x)$, scattered throughout the slide; Heavy infection (4): More than 40 hypnospores observed in a total of 10 random fields $(400 \mathrm{x})$, scattered throughout the slide.

The mean intensity of infection was calculated as the mean intensity considering only the infected oysters (1-4). The prevalence of infection was calculated as the percentage of infected oysters in each sample.

\section{DNA extraction}

A demibranch fragment or the entire oyster was sampled and immediately preserved in 95\% ethanol for molecular analyses. For adult and juvenile oysters, a small fragment of the gill was removed from each animal $(30-40 \mathrm{mg} ; \mathrm{n}=40)$ and individually analyzed. For spats from the hatchery, due to their small size, groups of whole spats were sampled by weight ( $400 \mathrm{mg} ; \mathrm{n}=9$ ). For spats from the nursery, gill fragments from 10 oysters were grouped together $(30-40 \mathrm{mg} ; \mathrm{n}=5)$; in this case, the oysters were not the same as those used for the diagnosis of Perkinsus spp. by RFTM.

Table 1. Oyster samplings performed during the production stages at the PRIMAR farm and analyses performed. RFTM: Ray's fluid thioglycolate medium analysis; PCR-ITS: used for the identification of the Perkinsus genus; PCR-RFLP: used for the identification of the oyster species. Spats: $\leq 2 \mathrm{~cm}$; Juveniles: $>2<5 \mathrm{~cm}$; Adults $\geq 5 \mathrm{~cm}$.

\begin{tabular}{|c|c|c|c|c|}
\hline Date & Production stages & RFTM & PCR-ITS & PCR-RFLP 16S \\
\hline $02 / 01 / 13$ & Broodstock ( $\geq 3$ years) & 10 & 6 & 4 \\
\hline $04 / 23 / 14$ & Broodstock (used for spawning) & 12 & 12 & 12 \\
\hline $05 / 24 / 14$ & Spats (hatchery) & nd & $9^{*}$ & $9^{*}$ \\
\hline $07 / 16 / 14$ & Spats (ponds) & 50 & $5^{*}$ & nd \\
\hline $10 / 10 / 14$ & Juveniles ( 3 months ${ }^{* *}$ ) so & 50 & 4 & nd \\
\hline $02 / 06 / 15$ & Juveniles (7 months ${ }^{* *}$ ) so & 30 & 4 & nd \\
\hline $03 / 09 / 15$ & Adults $\left(8 \text { months }^{* *}\right)^{\text {Lo }}$ & 10 & 4 & nd \\
\hline $05 / 22 / 15$ & Adults $\left(10\right.$ months $\left.s^{* *}\right)$ so & 100 & 10 & nd \\
\hline TOTAL & & 262 & 54 & 25 \\
\hline
\end{tabular}

nd: not done. ${ }^{*}$ groups of spats. ${ }^{* *}$ elapsed time after oysters deployment in ponds. LO: larger oysters. SO: smaller oysters. 
Deoxyribonucleic acid (DNA) was extracted from each sample using the Wizard ${ }^{\oplus}$ Genomic DNA Purification Kit (Promega) following the manufacturer's instructions and used for Perkinsus spp. confirmation and oyster species identification.

\section{PCR analysis to confirm the genus Perkinsus}

To confirm the presence of Perkinsus spp. $(\mathrm{n}=54$; Table 1$)$, polymerase chain reaction (PCR) assay was prepared using a pair of Perkinsus genus-specific primers, PerkITS85 / PerkITS750 (CASAS et al., 2002). These primers specifically hybridize to the conserved regions of the ribosomal ribonucleic acid (RNA) gene, including internal transcribed spacer 1 (ITS), the $5.8 \mathrm{~S}$ gene and ITS2 (ITS rDNA). The reactions were performed in a total volume of $25 \mu \mathrm{L}$ containing $1 \mu \mathrm{L}$ of genomic DNA (50 - $200 \mathrm{ng}$ ), 1x PCR buffer, $1.5 \mathrm{mM} \mathrm{MgCl}_{2}, 0.2 \mathrm{mM}$ nucleotides, $0.4 \mu \mathrm{M}$ primers and $0.04 \mathrm{U} / \mu \mathrm{L}$ Taq DNA polymerase. The reaction conditions for amplification included DNA denaturation at $94^{\circ} \mathrm{C}$ for $10 \mathrm{~min}$, followed by 40 cycles of $94^{\circ} \mathrm{C}$ for $1 \mathrm{~min}, 58^{\circ} \mathrm{C}$ for $1 \mathrm{~min}$ and $72^{\circ} \mathrm{C}$ for $1 \mathrm{~min}$, with a final $10 \mathrm{~min}$ elongation step at $72{ }^{\circ} \mathrm{C}$. The expected product size was $703 \mathrm{bp}$. Deoxyribonucleic acid samples isolated from oysters infected with $P$. marinus (SILVA et al., 2013) and P. beihaiensis (SABRY et al., 2009) were used as controls. The PCR amplification products were stained with Blue Green Loading Dye I (LGC Biotecnologia) and resolved via electrophoresis in 1\% agarose gels.

\section{Identification of oyster species by PCR-RFLP}

Oysters show high levels of morphologic phenotypic plasticity, which makes differentiation among species extremely difficult (AMARAL \& SIMONE, 2014). In this study, to identify the Crassostrea species $(\mathrm{n}=25$; Table 1$)$, the mitochondrial gene encoding the small ribosomal subunit (16S) was amplified using the primers 16SAR/16SBR (KESSING et al., 1989). The PCR assays were prepared in a total volume of $25 \mu \mathrm{L}$ containing $1 \mu \mathrm{L}$ of genomic DNA (50 - $200 \mathrm{ng}$ ), 1x PCR buffer, $1.5 \mathrm{mM} \mathrm{MgCl}$, $0.2 \mathrm{mM}$ nucleotides, $0.4 \mu \mathrm{M}$ primers and $0.04 \mathrm{U} / \mu \mathrm{L}$ Taq DNA polymerase. The conditions for the amplification reaction included DNA denaturation at $94^{\circ} \mathrm{C}$ for $10 \mathrm{~min}$, followed by 30 cycles of $94^{\circ} \mathrm{C}$ for $1 \mathrm{~min}, 50{ }^{\circ} \mathrm{C}$ for $1 \mathrm{~min}$ and $72{ }^{\circ} \mathrm{C}$ for $1 \mathrm{~min}$, with a final 10 min elongation step at $72{ }^{\circ} \mathrm{C}$. The expected product size was 560 bp. Samples of DNA from C. gasar (SILVA et al., 2014), C. rhizophorae (SILVA et al., 2013) and C. gigas (provided by the Laboratory of Immunology Applied to Aquaculture, UFSC), were used as controls. The PCR amplification products were stained with Blue Green Loading Dye I (LGC Biotecnologia) and resolved via electrophoresis in 1\% agarose gels.

The 16 S amplification products generated by PCR were digested with the enzyme $A l u$ I according to the manufacturer's instructions (Promega), as described by Lazoski (2004). The digestion reactions were prepared in a final volume of $20 \mu \mathrm{L}$, containing $2 \mu \mathrm{g}$ of the PCR product, $2 \mu \mathrm{L}$ of reaction buffer, $0.2 \mu \mathrm{L}$ of BSA and $0.5 \mu \mathrm{L}$ of the restriction enzyme diluted in ultrapure water. The obtained Restriction Fragment Length Polymorphism (RFLP) patterns were compared with those observed following the digestion of DNA from the C. gigas, C. gasar and C. rhizophorae controls.
Aliquots of $10 \mu \mathrm{L}$ of the digestion products were resolved on $8 \%$ polyacrylamide non-denaturing gels, which were stained with the Gel Red ${ }^{\text {TM }}$ Nucleic Acid Gel Stain (Biotium) for 20 min.

\section{Results}

\section{Identification of oyster species}

Oysters from the different production stages were analyzed by PCR, and a fragment of the expected size of $560 \mathrm{bp}$ was produced. The analysis of these fragments digested with endonuclease $A l u \mathrm{I}$ showed a pattern consistent with the control corresponding to the species C. gasar. This pattern is shown in Figure 1, consisting of a large $250 \mathrm{bp}$ fragment and a group of small $100 \mathrm{bp}$ fragments.

\section{Monitoring of Perkinsus spp. on the PRIMAR farm}

Perkinsus spp. infection was evaluated in oysters during all production stages, from broodstock to commercial size. The parasitic indices determined for the oysters analyzed in this study are shown in Table 2. Perkinsus spp. infections were confirmed by PCR for all sampling dates (Figure 2).

The broodstock analyzed in 2013 showed a high prevalence (60\%) but a low-intensity of Perkinsus spp. infection (1.17 \pm 0.41$)$. In contrast, the breeder oysters used for spawning in 2014 presented a high prevalence $(75 \%)$ and moderate intensity of infection $(2.78 \pm 0.44)$. However, the spats obtained from the spawning of these breeders were negative for Perkinsus spp. infection during the period in which they were kept inside the hatchery. When the spats were transferred to the pond, where they came into contact with water from the shrimp pond, they acquired the infection $(46 \%)$, but at a low intensity $(1.08 \pm 0.28)$. The growth of spats

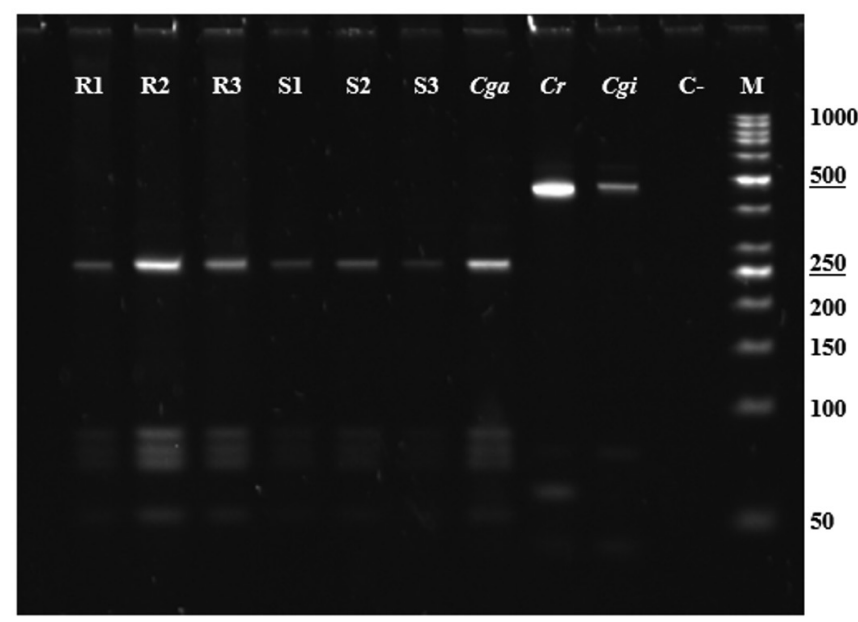

Figure 1. Fragmentation profile of the $16 \mathrm{~S}$ mitochondrial gene from oysters sampled at different stages of culture, after digestion with the endonuclease AluI, resolved on an $8 \%$ polyacrylamide gel. Samples of breeder oysters (R1, R2 and R3) and spats (S1, S2 and S3). DNA controls for C. gasar (Cga), C. rhizophorae $(C r)$ and C. gigas (Cgi). $\mathrm{C}$ : negative control for PCR assays. M: $50 \mathrm{bp}$ molecular weight marker (Thermo). 
Table 2. Parasitic indices [prevalence (Prev.) and intensity of infection by Perkinsus sp. (Int.)] obtained by Ray's fluid thioglycolate medium analysis (RFTM) in Crassostrea gasar oysters sampled during the production stages at the PRIMAR farm and confirmation of the genus Perkinsus by PCR. $\mathrm{N}$ = number of samples tested by RFTM or PCR.

\begin{tabular}{|c|c|c|c|c|c|c|}
\hline \multirow{2}{*}{ Production stages } & \multirow{2}{*}{ Size $(\mathbf{c m})$} & \multicolumn{3}{|c|}{ Parasitic indices } & \multicolumn{2}{|c|}{ Results of PCR } \\
\hline & & Prev. (\%) & Int. (1-4) & N (RFTM) & Positive & N (PCR) \\
\hline Broodstock ( $\geq 3$ years) & $10.1 \pm 0.68$ & 60 & $1.17 \pm 0.41$ & 10 & 4 & 6 \\
\hline Broodstock (used for spawning) & $12.3 \pm 1.01$ & 75 & $2.78 \pm 0.44$ & 12 & 9 & 12 \\
\hline Spats (hatchery) & nd & nd & nd & nd & 0 & $9^{*}$ \\
\hline Spats (ponds) & $1.7 \pm 0.20$ & 46 & $1.08 \pm 0.28$ & 50 & 3 & $5^{*}$ \\
\hline Juveniles ( 3 months ${ }^{* *}$ ) & $4.3 \pm 0.58$ so & 56 & $2.28 \pm 1.26$ & 50 & 4 & 4 \\
\hline Juveniles (7 months ${ }^{* *}$ ) & $4.5 \pm 0.59$ so & 73 & $1.27 \pm 0.46$ & 30 & 1 & 4 \\
\hline Adults (8 months $\left.{ }^{* *}\right)$ & $7.1 \pm 0.68^{\text {LO }}$ & 50 & $2.80 \pm 1.64$ & 10 & 3 & 4 \\
\hline Adults (10 months**) & $5.3 \pm 0.89$ so & 17 & $3.94 \pm 0.24$ & 100 & 1 & 4 \\
\hline
\end{tabular}

nd: not determined. ${ }^{*}$ groups of spats. ${ }^{* *}$ elapsed time after oysters deployment in ponds. LO: larger oysters. SO: smaller oyster.

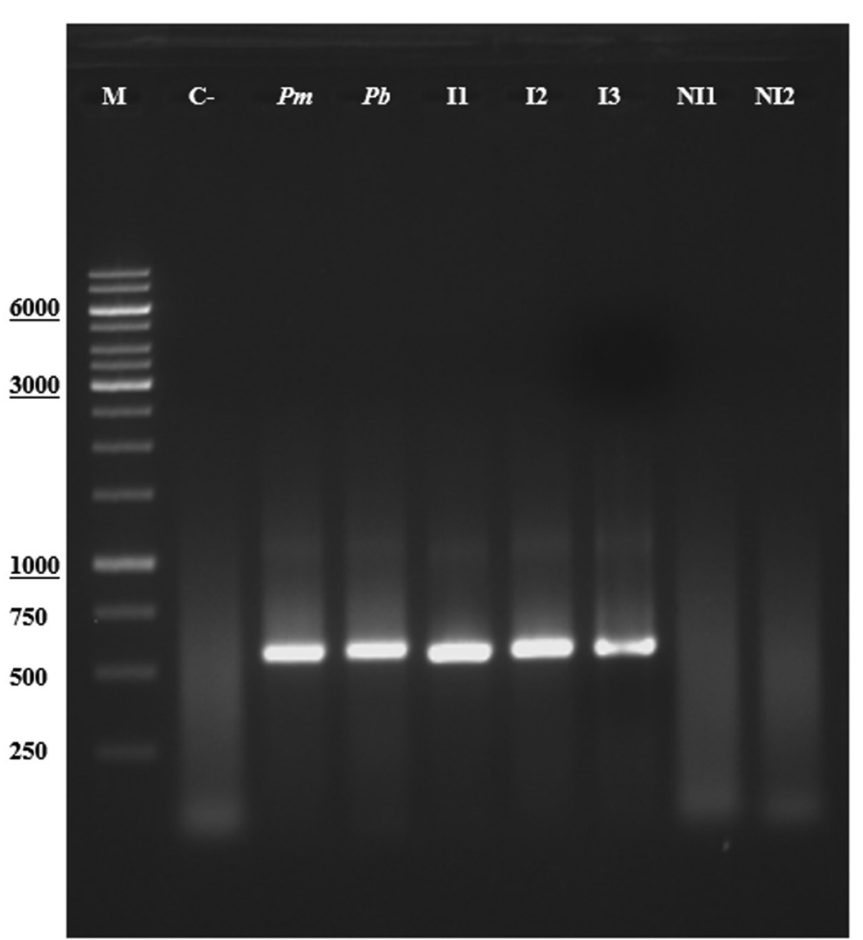

Figure 2. Agarose gel electrophoresis (1\%) of the ITS rDNA fragments from genus Perkinsus amplified from DNA from C. gasar oysters sampled at different stages of culture. Perkinsus-infected oysters (I1, I2, I3) and non-infected oysters (NI1, NI2). Positive controls with $P$. marinus $(P m)$ and $P$. beihaiensis $(P b) . \mathrm{M}: 1 \mathrm{~Kb}$ molecular weight marker (Thermo).

in ponds increased the prevalence of Perkinsus spp. to 56\% three months after placement in the ponds (October 2014), and to $73 \%$ at seven months after placement (February 2015) (Table 2). Then, the prevalence of Perkinsus spp. decreased in both groups of oysters: in the larger ones sampled in March (50\%) and in the smaller ones sampled in May (17\%). Interestingly, the intensity of infection in the larger oysters was higher $(2.8 \pm 1.64)$ than in the smaller oysters, sampled in February $(1.27 \pm 0.46)$, but not as high as that observed in oysters at the final stage of growth (3.94 \pm 0.24; Table 2).
Figure 3 shows the temperature and salinity of the shrimp pond from July 2014 to May 2015. Temperature did not vary (mean \pm SD: $29.0 \pm 1.1^{\circ} \mathrm{C}$ ), while salinity ranged from 25 to 40 psu (mean \pm SD: $32.8 \pm 5.3 \mathrm{psu}$ ).

\section{Oyster productivity traits}

Oysters cultured in shrimp ponds showed different growth rates. One group grew quicker and corresponded to the oysters selected and separated in July 2014 because of their larger size. Those oysters reached commercial size $(7.1 \mathrm{~cm})$ eight months after placement in the ponds. The other group grew slower and reached a small commercial size $(5.3 \mathrm{~cm}) 10$ months after placement in the ponds. In NE Brazil, oysters are commercialized starting at $5 \mathrm{~cm}$ in size. The growth rates of these two groups corresponded to 6.79 and $3.6 \mathrm{~mm}$ per month, respectively.

Although no sampling was specifically done to estimate oyster mortality during the growing stage in shrimp ponds, no abnormal mortality was reported during this period.

\section{Discussion}

This study analyzed the dynamics of Perkinsus spp. infection in a complete production system for native oysters for the first time in Brazil. The prevalence and intensity of Perkinsus spp. infection were determined in all stages of production, including (1) broodstock oysters, (2) spats in a hatchery, (3) spats in the shrimp ponds, (4) juvenile oysters, and (5) adult oysters until they reached $7 \mathrm{~cm}$ in a total of 13 months of growth.

The native oysters inhabiting estuaries in NE Brazil belong to at least two different species. Oysters of the species C. gasar show better growth under culture than those of the species $C$. rhizophorae (Dr. Carlos Gomes; personal communication), which has been previously reported for these species during the larval growth stage (CHRISTO et al., 2010). Therefore, in regions where both species can be found, $C$. gasar has garnered more interest in regard to oyster farming. In this study, all of the breeder oysters and, thus, their offspring belonged to a single species, C. gasar.

The results of this study indicate that broodstock oysters maintained for several years in the shrimp ponds at the PRIMAR 


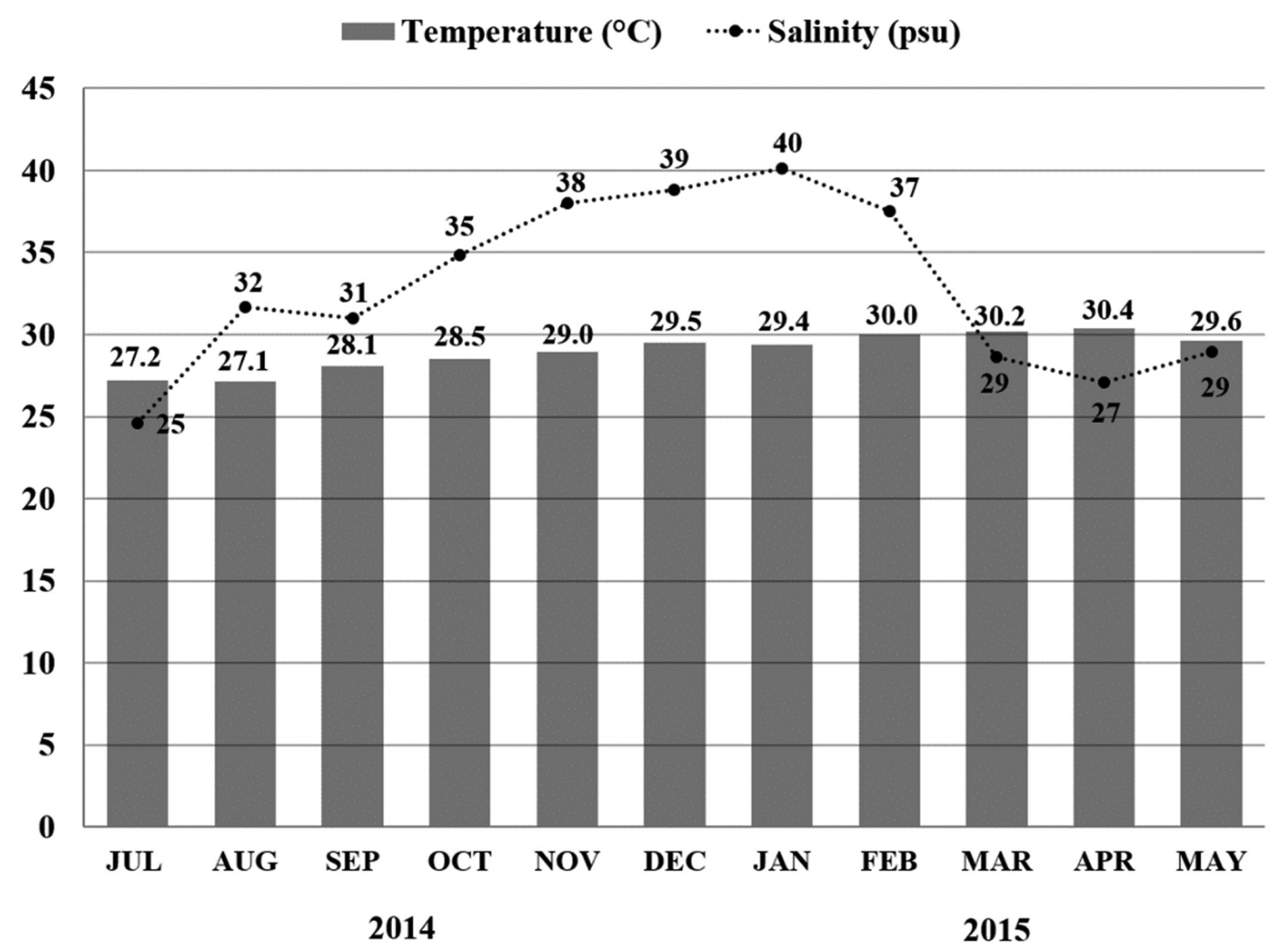

Figure 3. Water temperature $\left({ }^{\circ} \mathrm{C}\right.$ ) and salinity (psu) in the shrimp pond during the oysters' growing stage (July 2014 to May 2015 ).

farm were previously infected by Perkinsus spp. It is possible that the broodstock oysters had acquired the infection by direct contact with the estuary water that supplies the shrimp ponds from the Guaraíras lagoon, where there are also natural oyster populations. This hypothesis should be further investigated, as there are currently no studies on the prevalence of Perkinsus spp. in oysters at this location. This is therefore the first report of Perkinsus spp. in the state of Rio Grande do Norte.

The transmission of Perkinsus spp. parasites is known to occur through direct contact of healthy individuals (susceptible hosts) with water containing parasite cells released from infected individuals. There are no intermediate hosts and all stages of the parasite's lifecycle are infective (VILLALBA et al., 2004). Infection is thought to occur through at least two mechanisms: 1) via ingestion of the parasite into the gastrointestinal tract (TASUMI \& VASTA, 2007; CHU, 1996; BUSHEK et al., 2002), and 2) in the act of feeding through the oyster mantle during the rejection of pseudofeces at the labial palps (ALLAM et al., 2013). However, there are no existing studies on vertical transmission of Perkinsus spp., even though in cases with a severe intensity of infection, the gonad follicles can contain numerous parasite cells (CASAS \& VILLALBA, 2012; SILVA et al., 2015).

In the current study, transmission of Perkinsus spp. from parents to the offspring was not observed, as all of the spats samples ( $\mathrm{n}=9$; totaling $3.6 \mathrm{~g}$ ) were negative when analyzed by PCR. Studies conducted to evaluate different methods of eliminating
Perkinsus spp. have indicated that low-to-moderate levels of UV irradiation $\left(4,000\right.$ to $\left.14,000 \mu \mathrm{W} . \mathrm{s} / \mathrm{cm}^{2}\right)$ inhibit the proliferation of the parasite and that high levels $\left(>28,000 \mu \mathrm{W} . \mathrm{s} / \mathrm{cm}^{2}\right) \mathrm{kill}$ P. marinus cells (BUSHEK \& HOWELL, 2000). Moreover, high levels of UV irradiation $\left(60,000 \mu \mathrm{W} . \mathrm{s} / \mathrm{cm}^{2}\right)$ are required to kill P. olseni hypnospores (LESTER \& HAYWARD, 2005). Other methods, such as chlorination, are also effective in inactivating P. marinus and P. olseni cells (BUSHEK \& HOWELL, 2000; GOGGIN et al., 1990; BUSHEK et al., 1997). Both methods (chlorination and UV-C irradiation of water) are commonly used in bivalve hatcheries and were also employed at the PRIMAR facility, in addition to $1-\mu \mathrm{m}$ seawater filtration. In the present study, if Perkinsus spp. cells had been released from breeders during spawning, which lasted two days, the applied disinfection procedures would ultimately have led to the complete elimination of parasite cells. Therefore, this result clearly demonstrates the feasibility of producing Perkinsus-free oyster spats from infected broodstock and the possibility of further commercialization.

Currently, Brazilian law prevents the exportation of any bivalve species from a state with confirmed cases of $P$. marinus and $P$. olseni (notifiable species to the OIE). This situation recently occurred in the state of Paraíba (Ordinance No. 4 of the MPA, 31 January 2013; SILVA et al., 2013). These measurements, therefore, have negative consequences for oyster farming in NE Brazil. In this context, generating Perkinsus-free oysters is a promising alternative to sanitary controls in bivalves. 
The results of the present study also showed that when oyster spats (free of Perkinsus spp.) were exposed to water from the ponds, they were quickly infected by Perkinsus spp. (after two months). These infections likely occurred for at least two reasons: 1) spats were transferred to the same pond where broodstock oysters were kept, and 2) Perkinsus spp. were already present in the ponds and/or seawater estuary that supplied the shrimp ponds.

In this study, we observed a gradual increase in the prevalence of Perkinsus spp. infection (46\%, 56\% and 73\%) up to seven months after the spats had been transferred to the ponds, although the intensity was mild. This information indicates that individuals in the population acquired the infection slowly. However, 10 months after placement in the ponds, there was a sharp drop in the prevalence (17\%), and a significant increase in the intensity (3.94), of infection, the latter of which almost reached the highest possible level (4.0) at that time. Experimental infections of $C$. virginica oysters with $P$. marinus have indicated that there are two phases of infection: first, low-intensity infections associated with low mortality (after three weeks), and second, very heavy-intensity infections, with high mortality (after six weeks; FORD et al., 2002). It is possible that a similar pattern occurs in natural infections of P. marinus in Brazil, but with a longer duration. Despite the high prevalence $\left(73 \% ; 7^{\text {th }}\right.$ month) and intensity $\left(3.94 ; 10^{\text {th }}\right.$ month) of Perkinsus spp. infection, both conditions did not occur together, which might have contributed to the lack of mortality events during the growing stage of oysters. To date, massive mortality events have not been reported in cultured oysters from NE Brazil (Farmers, personal communication; SILVA et al., 2013, 2014; QUEIROGA et al., 2015).

In NE Brazil, the pattern of infection by Perkinsus spp. in oysters seems to be associated with salinity, i.e. the prevalence and parasite burden decrease at low salinities, which usually occurs in the rainy season (BRANDÃO et al., 2013; SILVA et al., 2014; QUEIROGA et al., 2015). Accordingly, in the shrimp pond, high salinity (37 to $40 \mathrm{psu}$ ) accumulated during November 2014 to February 2015, could have contributed to the highest prevalence of Perkinsus spp. (73\%) observed in February 2015. However, studies linking physical parameters of the seawater, Perkinsus spp. infection dynamics, and productive traits (growth and mortality) are missing and must be explored in future experiments to fully understand the impact of Perkinsus spp. disease in cultured oysters in Brazil.

Another interesting observation made in the present study was that the larger oysters that reached a commercial size in March ( $8^{\text {th }}$ month of culture in the ponds) showed a lower prevalence of infection than the smaller ones $(50 \%$ vs. $73 \%)$, but their intensity of infection was higher (2.80 vs. 1.27$)$. It is possible that their larger size and, therefore, larger gill area led to a higher filtration rate (EHRICH \& HARRIS, 2015), which would result in increased ingestion of parasite cells, thus favoring infection. Paynter et al. (2010) showed that prevalence and intensity of $P$. marinus infection increased with the age of $C$. virginica oysters, which was highly correlated with oyster shell height and dry tissue weight. In C. gasar, despite the lowest prevalence, the parasite burden was higher in tissues of larger oysters.

A single study evaluated the feasibility of C. gasar oysters growing and surviving in shrimp ponds in the Sergipe state (NE,
Brazil) (ROSA, 2014). Crassostrea gasar oysters with an initial size of $4 \mathrm{~cm}$ were growth for just four months; the results showed reduced growth rate $(2.37 \mathrm{~mm}$ per month). In the current study, growth rates were more variable and higher $(3.6$ and $6.79 \mathrm{~mm}$ per month) than the previous study, and even higher than those (2.16-2.64 mm per month) found by Pereira et al. (2001) for C. gasar cultured by traditional rack methods in São Paulo state.

In conclusion, this is the first study in Brazil to evaluate the presence of Perkinsus spp. at all stages of $C$. gasar oyster production, and the case described herein is also the first reported in the state of Rio Grande do Norte (NE Brazil). The results of this study also showed that it is possible to produce Perkinsus-free C. gasar oyster spats from infected broodstock, and that their production in shrimp ponds is feasible.

\section{Acknowledgements}

We thank the Conselho Nacional de Desenvolvimento Cientifico e Tecnológico-CNPq for financial support to the project CNPq/MPA No. 406170/2012-6. We thank to Universidade Federal da Paraíba for English editing service. We thank to Sâmia Sousa Duarte for the technical assistance.

\section{References}

Allam B, Carden WE, Ward JE, Ralph G, Winnick S, Espinosa EP. Early host-pathogen interactions in marine bivalves: evidence that the alveolate parasite Perkinsus marinus infects through the oyster mantle during rejection of pseudofeces. J Invertebr Pathol 2013; 113(1): 26-34. http://dx.doi.org/10.1016/j.jip.2012.12.011. PMid:23274079.

Amaral VS, Simone LRL. Revision of genus Crassostrea (Bivalvia: Ostreidae) of Brazil. J Mar Biol Assoc UK 2014; 94(4): 811-836. http:// dx.doi.org/10.1017/S0025315414000058.

Brandão RP, Boehs G, Sabry RC, Ceuta LO, Luz MSA, Queiroga FR, et al. Perkinsus sp. infecting oyster Crassostrea rhizophorae (Guilding, 1828) on the coast of Bahia, Brazil. J Invertebr Pathol 2013; 112(2): 138-141. http://dx.doi.org/10.1016/j.jip.2012.11.003. PMid:23201453.

Bushek D, Holley RA, Kelly MC. Treatment of Perkinsus marinus: contaminated materials. J Shellfish Res 1997; 16: 330.

Bushek D, Howell TL. The effect of UV irradiation on perkinsus marinus and its potential use to reduce transmission via shellfish effluents [online]. North Dartmouth: Northeastern Regional Aquaculture Center; 2000. 4 p. Publication No. 00-008. [cited 2015 June 28]. Available from: https:// agresearch.umd.edu/sites/default/files/_docs/00-008\%20Shellfish.pdf

Bushek D, Scarpa J, Laramore SE. Susceptibility of the Caribbean oyster Crassostrea rhizophorae to Perkinsus marinus. J Shellfish Res 2002; 21: 371-372.

Casas SM, Villalba A, Reece KS. Study of perkinsosis in the carpet shell clam Tapes decussatus in Galicia (NW Spain). I. Identification of the aetiological agent and in vitro modulation of zoosporulation by temperature and salinity. Dis Aquat Organ 2002; 50(1): 51-65. http:// dx.doi.org/10.3354/dao050051. PMid:12152905.

Casas SM, Villalba A. Study of perkinsosis in the grooved carpet shell clam Ruditapes decussatus in Galicia (NW Spain). III. The effects of Perkinsus 
olseni infection on clam reproduction. Aquaculture 2012; 356-357: 4047. http://dx.doi.org/10.1016/j.aquaculture.2012.05.038.

Choi KS, Park KI. Review on the protozoan parasite Perkinsus olseni (Lester and Davis 1981) infection in Asian waters. In: Ishimatsu A, Lie HJ. Coastal environmental and ecosystem issues of the east China sea. Nagazaki: TERRAPUB, Nagasaki University; 2010. p. 269-281.

Christo SW, Absher TM, Boehs G. Morphology of the larval shell of three oyster species of the genus Crassostrea Sacco, 1897 (Bivalvia: Ostreidae). Braz J Biol 2010; 70(3): 645-650. http://dx.doi.org/10.1590/S151969842010000300023. PMid:20730353.

Chu FLE. Laboratory investigations of susceptibility, infectivity, and transmission of Perkinsus marinus in oysters. J Shellfish Res 1996; 15: 57-66.

Ehrich MK, Harris LA. A review of existing eastern oyster filtration rate models. Ecol Modell 2015; 297: 201-212. http://dx.doi.org/10.1016/j. ecolmodel.2014.11.023.

Empresa de Pesquisa Agropecuária e Extensão Rural de Santa Catarina - EPAGRI. Sintese informativa da maricultura [online]. Florianópolis: EPAGRI; 2014 [cited 2015 June 28]. Available from: http://www. epagri.sc.gov.br/wp-content/uploads/2013/08/Sintese_informativa_da_ maricultura_2014.pdf

Ferreira LP, Sabry RC, Silva PM, Gesteira TCV, Romão LS, Paz MP, et al. First report of Perkinsus beihaiensis in wild clams Anomalocardia brasiliana (Bivalvia: Veneridae) in Brazil. Exp Parasitol 2015; 150: 67-70. http:// dx.doi.org/10.1016/j.exppara.2014.07.012. PMid:25088443.

Ford SE, Chintala MM, Bushek D. Comparison of in vitro-cultured and wild-type Perkinsus marinus. I. Pathogen virulence. Dis Aquat Organ 2002; 51(3): 187-201. http://dx.doi.org/10.3354/dao051187. PMid:12465877.

Goggin CL, Sewel KB, Lester RJG. Tolerances of Perkinsus spp. (Protozoa, Apicomplexa) to temperature, chlorine and salinity. J Shellfish Res 1990 9: $145-148$.

Gomes CHAM, Silva FC, Lopes GR, Melo CMR. The reproductive cycle of the oyster Crassostrea gasar. Braz J Biol 2014; 74(4): 967-976. http:// dx.doi.org/10.1590/1519-6984.04912. PMid:25627610.

Jones AB, Dennison WC, Preston NP. Integrated treatment of shrimp effluent by sedimentation, oyster filtration and macroalgal absorption: a laboratory scale study. Aquaculture 2001; 193(1-2): 155-178. http:// dx.doi.org/10.1016/S0044-8486(00)00486-5.

Jones AB, Preston NP. Sydney rock oyster, Saccostrea commercialis (Iredale $\&$ Roughley), filtration of shrimp farm effluent: the effects on water quality. Aquacult Res 1999; 30(1): 51-57. http://dx.doi.org/10.1046/j.13652109.1999.00299.x.

Kessing B, Croom H, Martin A, McIntosh C, Owen M, Palumbi S. A simple guide to PCR. Honolulu: Department of Zoology, University of Hawaii; 1989.

Lauckner G. Diseases of mollusca: bivalvia. In: Kinne O. Diseases of marine animals. Hamburg: Biologische Anstalt Helgoland; 1983. p. 477-961.

Lavander HD, Cardoso LO Jr, Silva LOB, Gàlvez AO. Estudo de viabilidade econômica para ostreicultura familiar em Pernambuco, Brasil. Custose @gronegócio Online 2013; 9(2): 173-187.

Lazoski CVS. Sistemática molecular e genética populacional de ostras brasileiras (Crassostrea spp.) [Thesis] Rio de Janeiro: Universidade Federal do Rio de Janeiro; 2004.
Lester RJG, Hayward CJ. Control of Perkinsus disease in abalone. Brisbane: University of Queensland, Fisheries Research and Development Corporation; 2005. Project 2000/151 Final Report.

Lopes GR, Gomes CHAM, Tureck CR, Melo CMR. Growth of Crassostrea gasar cultured in marine and estuary environments in brazilian waters. Pesq Agropec Brasil 2013; 48(8): 975-982. http://dx.doi.org/10.1590/ S0100-204X2013000800024.

Martinez-Cordova LR, Martinez-Porchas M. Polyculture of pacific white shrimp, Litopenaeus vannamei, giant oyster, Crassostrea gigas and black clam, Chione fluctifraga in ponds in Sonora, Mexico. Aquaculture 2006; 258(1-4): 321-326. http://dx.doi.org/10.1016/j.aquaculture.2006.03.026.

Martínez-Porchas M, Martínez-Córdova LR, Pórchas-Cornejo MA, López-Elías JA. Shrimp polyculture: a potentially profitable, sustainable, but uncommon aquacultural pratice. Rev Aquaculture 2010; 2(2): 73-85. http://dx.doi.org/10.1111/j.1753-5131.2010.01023.x.

Páez-Osuna F. The environmental impact of shrimp aquaculture: causes, effects, and mitigating alternatives. Environ Manage 2001; 28(1): 131140. http://dx.doi.org/10.1007/s002670010212. PMid:11436996.

Paynter KT, Politano V, Lane HA, Allen SM, Meritt D. Growth rates and prevalence of Perkinsus marinus prevalence in restored oyster populations in Maryland. J Shellfish Res 2010; 29(2): 309-317. http:// dx.doi.org/10.2983/035.029.0205.

Pereira OM, Machado IC, Henriques MB, Yamanaka N. Crescimento da ostra Crassostrea brasiliana semeada sobre tabuleiro em diferentes densidades na região estuarino-lagunar de Cananéia-SP $\left(25^{\circ} \mathrm{S}, 48^{\circ} \mathrm{W}\right)$. Bol Inst Pesca SP 2001; 27(2): 163-174.

Queiroga FR, Vianna RT, Vieira CB, Farias ND, Silva PM. Parasites infecting the cultured oyster Crassostrea gasar (Adanson, 1757) in Northeast Brazil. Parasitology 2015; 142(6): 756-766. http://dx.doi.org/10.1017/ S0031182014001863. PMid:25553815.

Ramos CO, Gomes CHAM, Magalhães ARM, Santos AI, Melo CMR. Maturation of the mangrove oyster Crassostrea gasar at diferent temperatures in the laboratory. J Shellfish Res 2014; 33(1): 187-194. http://dx.doi. org/10.2983/035.033.0118.

Ramos R, Vinatea L, Costa R. Tratamiento de efluentes del cultivo de Litopenaeus vannamei por sedimentación y filtración por la ostra Crassostrea rhizophorae. Lat Am J Aquat Res 2008; 36(2): 235-244. http://dx.doi. org/10.3856/vol36-issue2-fulltext-6.

Reyes GG. Mixed culture (shrimps, oysters and macroalgae) to improve the productivity, and reduce the environmental impact to coastal ecosystem caused by shrimp hatcheries in Mexico. Int J Fish Aquacult 2013; 5(10): 262-269.

Rosa LC. Crescimento e sobrevivência da ostra Crassostrea brasiliana (Lamarck, 1819) mantida em um viveiro de cultivo de camaráo. Arq. Cienc Mar 2014; 47(1): 64-68.

Sabry RC, Gesteira TCV, Magalhães ARM, Barracco MA, Guertler C, Ferreira LP, et al. Parasitological survey of mangrove oyster, Crassostrea rhizophorae, in the Pacoti River Estuary, Ceará State, Brazil. J Invertebr Pathol 2013; 112(1): 24-32. http://dx.doi.org/10.1016/j.jip.2012.10.004. PMid:23147104.

Sabry RC, Rosa RD, Magalhães ARM, Barracco MA, Gesteira TCV, Silva PM. First report of Perkinsus sp. infecting mangrove oysters Crassostrea rhizophorae from the Brazilian coast. Dis Aquat Organ 2009; 88(1): $13-$ 23. http://dx.doi.org/10.3354/dao02136. PMid:20183961.

Silva PM, Vianna RT, Guertler C, Ferreira LP, Santana LN, FernandézBoo $S$, et al. First report of the protozoan parasite Perkinsus marinus in 
South America, infecting mangrove oysters Crassostrea rhizophorae from the Paraíba River. J Invertebr Pathol 2013; 113(1): 96-103. http://dx.doi. org/10.1016/j.jip.2013.02.002. PMid:23439264.

Silva PM, Scardua MP, Vianna RT, Mendonça RC, Vieira CB, Dungan CF, et al. Two Perkinsus spp. infect Crassostrea gasar oysters from cultured and wild populations of the Rio São Francisco estuary, Sergipe, northeastern Brazil. J Invertebr Pathol 2014; 119: 62-71. http://dx.doi.org/10.1016/j. jip.2014.04.005. PMid:24780219.

Silva PM, Scardua MP, Vieira CB, Alves AC, Dungan CF. Survey of pathologies in Crassostrea gasar (Adanson, 1757) oysters from cultured and wild populations in the São Francisco estuary, Sergipe, northeast Brazil. J Shellfish Res 2015; 34(2): 289-296. http://dx.doi.org/10.2983/035.034.0210.

Silveira RC, Silva FC, Gomes CHM, Ferreira JF, Melo CMR. Larval settlement and spat recovery rates of the oyster Crassostrea brasiliana (Lamarck, 1819) using different systems to induce metamorphosis. Braz J Biol 2011; 71(2): 557-562. http://dx.doi.org/10.1590/S151969842011000300029. PMid:21755177.

Tasumi S, Vasta GR. A Galectin of unique domain organization from hemocytes of the eastern oyster (Crassostrea virginica) is a receptor for the protistan parasite Perkinsus marinus. J Immunol 2007; 179(5): 3086-3098. http://dx.doi.org/10.4049/jimmunol.179.5.3086. PMid:17709523.

Villalba A, Gestal C, Casas SM, Figueras A. Perkinsosis en moluscos. In: Figueras A, Novoa B. Enfermedades de moluscos bilvalvos de interés en acuicultura. Madrid: Fundación Observatorio Español de Acuicultura; 2011. p. 181-242.

Villalba A, Reece KS, Ordás MC, Casas SM, Figueras A. Perkinsosis in molluscs: a review. Aquat Living Resour 2004; 17(4): 411-432. http:// dx.doi.org/10.1051/alr:2004050.

World Organization for Animal Health - OIE. Manual of diagnostic tests for aquatic animals. 5th ed. Paris: OIE; 2006.

World Organization for Animal Health - OIE. OIE Listed diseases, infections and infestations in force in 2015. Paris: OIE; 2015 [cited 2015 June 28]. Available from: http://www.oie.int/animal-health-in-the-world/ oie-listed-diseases-2015

Xie B, Jiang W, Yang H. Growth perfomance and nutrient quality of Chinese shrimp Penaeus chinensis in organic polyculture with razor clam Sinovacula constricta or hard clam Meretix meretrix. BulgJ Agric Sci 2011; 17(6): 851-858. 